\title{
KOMBINASI MEDIA TANAM DAN PENAMBAHAN PUPUK ORGANIK CAIR TERHADAP PERTUMBUHAN DAN PRODUKSI TANAMAN CABE
}

\author{
Helfi Gustia* dan Rosdiana \\ Program Studi Agroteknologi Fakultas Pertanian Universitas Muhammadiyah Jakarta \\ Jl. K.H. Ahmad Dahlan, Cirendeu Ciputat-15419 \\ Telp.0217430689, HP 08129989896 \\ *E-mail: helfi.umj@gmail.com
}

\begin{abstract}
ABSTRAK
Pertumbuhan dan produksi cabe dapat dipengaruhi antara lain oleh teknik budidaya belum optimal dan faktor kesesuaian lahan kurang mendukung. Salah satu upaya meningkatkan produktivitas dengan kombinasi media tanam dan penambahan pupuk organik cair (POC) pada tanaman cabe. Pelaksanaan penelitian di Pondok Benda Indah pada bulan Februari sampai Mei 2018. Tujuan penelitian memperoleh media dan dosis POC yang sesuai serta pengaruh interaksi media tanam dan POC pada tanaman cabe. Penelitian menggunakan Rancangan Acak Kelompok (RAK) dengan pola factorial. Faktor pertama media tanam M1(tanah + pupuk kandang = 1:1) dan M2 (tanah + pupuk kandang + sekam bakar $=1: 1: 1)$. Faktor kedua penambahan POC yakni P1 $(100 \% \mathrm{NPK})$, P2 (70\% NPK + 50 ml.tanaman-1 POC), P3 (70\% NPK + 100 ml.tanaman-1 POC), P4 $(70 \%$ NPK +150 ml.tanaman-1 POC). Parameter yang diamati tinggi tanaman, jumlah cabang, panjang buah, bobot buah buah ${ }^{-1}$, dan bobot buah per tanaman. Hasil penelitian memperlihatkan kombinasi media tanam dan penambahan POC berpengaruh nyata terhadap pertumbuhan dan produksi tanaman cabe. Kombinasi media tanam (tanah + pupuk kandang kambing + sekam bakar) menunjukkan tinggi tanaman tertinggi. Perlakuan P4 menghasilkan jumlah cabang terbanyak, panjang buah terpanjang, bobot buah buah ${ }^{-1}$ dan bobot buah per tanaman terberat. Interaksi kombinasi media tanam M2 dan P4 menunjukkan tanaman tertinggi, jumlah cabang terbanyak, bobot buah buah ${ }^{-1}$ dan bobot buah per tanaman terberat.
\end{abstract}

Kata kunci: Pupuk anorganik, pupuk organik cair, sekam bakar

\section{ABSTRACT}

Growth and chilli production can be influenced by, among others, cultivation techniques that are not optimal and land suitability factors are less supportive. One of the efforts to increase productivity is a combination of planting media and the addition of liquid organic fertilizer (LOF) to chillies. The research was conducted at Pondok Benda Indah from February to May 2018. The purpose of the study was to obtain the appropriate media and LOF dosage and the effect of the interaction of planting media and POC on chilli plants. The study used a Randomized Complete Block Design (RCBD) with factorial patterns. The first factor is planting media M1 (soil + manure = 1: 1) and M2 (soil + manure + fuel husk =1: 1: 1). The second factor is the addition of LOF P1 (100\% NPK), P2 (70\% NPK + $50 \mathrm{ml} \mathrm{plant}^{-1}$ LOF), P3 (70\% NPK + $100 \mathrm{ml} \mathrm{plant}^{-1}$ LOF), P4 (70\% 
$N P K+150 \mathrm{ml}$ plant $^{-1}$ LOF). The parameters observed were plant height, number of branches, fruit length, fruit weight ${ }^{-1}$, and fruit weight of plant ${ }^{-1}$. The results showed the combination of planting media and the addition of LOF significantly affected the growth and production of chilli plants. The combination of M2 planting media shows the highest plant height. P4 treatment showed the highest number of branches, the longest fruit length, fruit weight ${ }^{-1}$ and the heaviest fruit weight of plant $^{-1}$. The interaction of the M2 and P4 planting media combination showed the highest plants, the highest number of branches, the heaviest fruit weight ${ }^{-1}$ and the heaviest fruit weight of plant ${ }^{-1}$ fruit.

Keywords: Inorganic fertilizer, liquid organic fertilizer, roasted husk

\section{PENDAHULUAN}

Mengharumkan nama Indonesia dimata dunia dapat dilakukan melalui sumber daya pertanian. Sumber daya tanaman sayuran merupakan salah satu potensi besar dari sektor pertanian (Rukmana dan Herdi, 2017). Tanaman cabe (Capsicum annuum L.) merupakan salah satu tanaman sayuran yang digolongkan ke dalam tanaman hortikultura.

Tanaman cabe berasal dari Meksiko, pada abad ke-15 berkembang di Eropa dan menyebar ke Amerika serta berbagai negara tropik. Pusat penyebaran cabe di Indonesia antara lain daerah Purworejo, Kebumen, Tegal, Pekalongan, Pati, Padang dan Bengkulu (Sunarjono, 2014). Menurut Dirjen Hortikultura (2015), kontribusi produksi cabe besar di Indonesia tahun 2014 berada pada urutan keempat, yaitu sebesar 1,074,602 ton (sekitar 9.02\%) terhadap produksi sayuran nasional.

Berdasarkan data BPS (2018), komoditas cabe besar menduduki posisi ke tiga dalam lima komoditas produksi sayuran semusim tahun 2017 setelah bawang merah dan kubis. Lima produksi terbesar komoditas sayuraan semusim tersebut adalah bawang merah mencapai 1.47 juta ton, kubis (1.44 juta ton), cabai besar (1.21 juta ton), kentang (1.16 juta ton), dan cabai rawit (1.15 juta ton).

Jika dilihat perkembangan luas panen dan rata-rata hasil cabe besar di Indonesia tahun 2012-2016, ada pertambahan luas panen setiap tahun, kecuali pada tahun 2015 terjadi penurunan luas panen. Produksi cabe besar tertinggi pada tahun 2014 $(1,074,602$ ton), dan produktifitas tertinggi terdapat pada tahun 2015 sebanyak 8.65 ton $\mathrm{Ha}^{-1}$ (Kementerian Pertanian, 2018).

Ketidak stabilan produksi dan produktifitas cabe dapat dipengaruhi oleh beberapa faktor, diantaranya varietas lokal yang berproduksi rendah, penggunaan teknologi budidaya belum optimal seperti dosis pupuk yang kurang tepat, faktor kesesuaian lahan yang kurang medukung (tanah, iklim, dan topografi). Oleh karena itu untuk memenuhi kebutuhan cabe, Indonesia masih mengimpor cabe dalam bentuk segar, kering, maupun bubuk.

Media tanam merupakan salah satu faktor lingkungan yang penting dalam mendapatkan unsur hara dan air pada budidaya tanaman. Agar tanaman dapat tumbuh dan berproduksi dengan optimal diperlukan media tanam yang baik seperti sekam bakar, pupuk organik, dll. Menurut Anonim (2007) cit. Cristiyani (2013), media tanam yang baik harus memiliki persyaratan tidak mengandung hama, penyakit dan bebas gulma, mampu menampung dan membuang kelebihan air, remah, porous, sehingga akar dapat tumbuh dan berkembang menembus media tanam dengan mudah, dan memiliki derajat keasaman antara $6,0-6,5$.

Berdasarkan hasil olahannya sekam padi dapat berupa sekam bakar dan sekam mentah (tidak dibakar). Porositas 
yang dimiliki oleh kedua jenis sekam ini adalah sama. Oleh sebab itu sebagai media tanam, sekam berperan penting dalam memperbaiki struktur tanah supaya sistem aerasi dan drainase media tanam menjadi lebih baik. Anonim (2009) menyatakan, sekam bakar adalah media tanam yang telah melewati proses pembakaran tetapi tidak sempurna dan berwarna hitam. Sekam bakar dibuat melalui proses penghentian pembakaran kulit gabah padi sebelum sekam jadi abu dengan cara ditutup atau disiram dengan air.

Menurut Marlina dan Rusnandi (2007), sekam bakar mengandung unsur $\mathrm{SiO} 2(52 \%), \mathrm{C}(31 \%), \mathrm{K}(0.3 \%), \mathrm{N}$ $(0,18 \%)$, F $(0,08 \%)$, dan kalsium $(0,14 \%)$. Di samping itu juga mengandung unsur lain lain dalam jumlah sedikit antara lain $\mathrm{Fe} 2 \mathrm{O} 3, \mathrm{~K} 2 \mathrm{O}$, $\mathrm{MgO}, \mathrm{CaO}, \mathrm{MnO}$, dan $\mathrm{Cu}$ serta beberapa jenis bahan organik. BPP Ketindan (2017) juga menambahkan, tingginya kandungan silikat pada sekam bakar dapat menjadikan tanaman lebih tahan terhadap hama dan penyakit akibat adanya pengerasan jaringan. Selain itu sekam bakar juga dapat digunakan penambah kadar Kalium dalam tanah.

Kecepatan penyerapan hara pupuk organik lebih lambat dibandingkan pupuk anorganik. Hal ini menyebabkan pertumbuhan tanaman yang menggunakan pupuk organik lebih lambat dibandingkan pupuk anorganik. Pupuk organik juga memiliki unsur hara yang lebih lengkap jika dibandingkan dengan pupuk anorganik (Nurahmi et al., 2011). Selain itu penggunaan pupuk anorganik dalam waktu lama dapat mengakibatkan ekosistem menjadi rusak.

Pupuk organik cair (POC) adalah pupuk organik berbentuk cairan. Umumnya POC merupakan hasil ekstrak bahan organik yang sudah dilarutkan dengan pelarut antara lain air, alkohol atau minyak. Senyawa organik mengandung karbon, vitamin, atau metabolik sekunder yang dapat bersumber dari ekstrak tanaman, tepung ikan, tepung tulang, atau enzim (Musnamar, 2005).

Unsur hara yang dikandung bahan organik adalah rendah. Dalam penelitian ini pupuk organik yang digunakan adalah pupuk kandang kambing. Menurut Hardjowigeno (2010), pupuk kandang kambing mengandung unsur hara $\mathrm{N} \mathrm{0,55 \% ,} \mathrm{P2O5} \mathrm{0,31 \% ,} \mathrm{dan} \mathrm{K} 2 \mathrm{O}$ $0.15 \%$. Bahan organik berperan dalam menyediakan hara makro dan mikro seperti $\mathrm{Zn}, \mathrm{Cu}, \mathrm{Mo}, \mathrm{Co}, \mathrm{Ca}, \mathrm{Mg}, \mathrm{Si}$; meningkatkan nilai tukar kation (KTK) tanah, dan dapat bereaksi dengan ion logam untuk membentuk senyawa kompleks, sehingga ion logam yang meracuni tanaman atau menghambat penyediaan hara seperti $\mathrm{Al}$. Fe,dan $\mathrm{Mn}$ dapat dikurangi (Setyorini, 2005). Hal tersebut yang melatarbelakangi dilaksanakannya penelitian ini.

Penelitian ini bertujuan untuk memperoleh media tanam dan dosis POC yang sesuai serta mengetahui pengaruh interaksi media tanam dan POC pada pertumbuhan dan produksi tanaman cabe.

\section{METODE}

Penelitian dilaksanakan di Pondok Benda Indah dari bulan Februari sampai bulan Mei 2018. Bahan yang digunakan dalam penelitian ini adalah benih cabe var. Lado F1®, polibag ukuran

$8 \times 9 \mathrm{~cm}$ dan $30 \times 40 \mathrm{~cm}$, tanah, pupuk kandang kambing, sekam bakar, pupuk organik cair D.I. Grow®, pupuk Urea, NPK Mutiara ${ }^{\circledR}$ pestisida Provibio ${ }^{\circledR}$, tali rafia, ajir, dan label. Alat yang dipakai cangkul, sodet, timbangan, gelas ukur, hand sprayer, gembor, meteran, alat tulis, dan kamera.

Penelitian ini menggunakan metode Rancangan Acak Kelompok (RAK) dengan pola faktorial. Faktor pertama 
adalah media tanam dengan dua perlakuan, yaitu M1 (tanah + pupuk kandang kambing) dan M2 (tanah + pupuk kandang kambing + sekam bakar). Faktor kedua dengan empat perlakuan yaitu P1 (100\% NPK), P2 (70\%. NPK + $50 \mathrm{ml} / \mathrm{tan} \mathrm{POC}), \mathrm{P} 3(70 \%$. $\mathrm{NPK}+100 \mathrm{ml} / \mathrm{tan} \mathrm{POC}), \mathrm{P} 4(70 \%$. NPK $+150 \mathrm{ml} / \tan$ POC). Penelitian ini seluruhnya ada delapan kombinasi perlakuan. Setiap satuan percobaan diulang empat kali, sehingga ada 32 satuan percobaan. Setiap satuan percobaan ada dua tanaman, seluruh satuan percobaan ada 64 tanaman. Uji lanjutan menggunakan Duncans New Multiple Range Test (DNMRT) pada taraf 5\%, dimana dalam analisis data ditransformasikan ke $\sqrt{ } \mathrm{x}+0.5$, melalui program Sirichai Statistics versi 6.07.

Media semai terdiri dari campuran tanah dan pupuk kandang dengan perbandingan 1:1, dimasukkan ke dalam polibag semai $8 \times 9 \mathrm{~cm}$. Media tanam yang digunakan sesuai perlakuan, yaitu tanah + pupuk kandang $=1: 1$ dicampurkan dan diaduk rata sebelum dimasukkan ke dalam masing-masing polibag berdiameter $30 \quad$ x $40 \quad \mathrm{~cm}$ sebanyak 48 polibag. Media tanam berupa tanah + pupuk kandang + sekam bakar $=1: 1: 1$ dicampurkan dan diaduk rata sebelum dimasukkan ke dalam polibag berdiameter $30 \quad$ x $40 \quad \mathrm{~cm}$ sebanyak 48 polibag. Dengan demikian media ditanam telah siap ditanami dengan bibit cabe var. Lado F1®.

Benih yang sudah diseleksi dimasukkan ke dalam polibag semai yang berisi media semai masing-masing sebanyak satu benih. Penyiraman pada persemaian dilakukan pagi dan sore (sesuai kondisi). Setelah bibit berumur 4 minggu dan berdaun tiga atau empat helai, dipindah tanamkan ke dalam polibag berukuran $30 \times 40 \mathrm{~cm}$ yang sudah berisi media tanam sesuai perlakuan.
Pemberian pupuk dilakukan pada 2 minggu setelah pemindahan bibit ke dalam masing-masing polibag, yaitu Urea sebanyak $7 \mathrm{~g}$ sebagai pupuk dasar, dan pupuk NPK Mutiara $10 \mathrm{~g}$ (100\%) diberikan saat tanaman berumur 6 mst. Saat tanaman berumur 15 dan 25 hari setelah tanam (hst) diberikan POC D.I. Grow Hijau ${ }^{\circledR}$ dengan konsentrasi $3 \mathrm{cc} \mathrm{L}$ ${ }^{1}$ air sesuai dosis, yaitu $50 \mathrm{ml}, 100 \mathrm{ml}$ dan $150 \mathrm{ml}$. Setelah tanaman cabe berumur 35 hst diberikan POC D.I. Grow Merah ${ }^{\circledR}$ sesuai dosis $(50 \mathrm{ml}, 100$ $\mathrm{ml}$ dan $150 \mathrm{ml}$ ) dengan konsentrasi $5 \mathrm{cc}$ $\mathrm{L}^{-1}$ air setiap seminggu sekali selama tiga kali kemudian minggu berikutnya disemprotkan D.I. Grow Hijauß dengan konsentrasi $3 \mathrm{cc} \mathrm{L}^{-1}$ air sesuai dosis (50 $\mathrm{ml}, 100 \mathrm{ml}$ dan $150 \mathrm{ml}$ ). Demikian seterusnya setelah tiga kali pemberian D.I. Grow Merah ${ }^{\circledR}$ dilanjutkan dengan satu kali pemberian D.I. Grow Hijau® ${ }^{\circledR}$.

Pemasangan ajir dilakukan segera setelah penanaman. Tinggi ajir $125 \mathrm{~cm}$ dengan jarak ajir dari batang $10 \mathrm{~cm}$. Penyiangan dan penggemburan dilakukan sekaligus, yaitu 2 mst dan selanjutnya setiap minggu (sesuai kondisi). Penyiraman dilakukan bersifat insidentil tergantung kondisi lapangan. Pengendalian hama dan penyakit bersifat kalender saat tanaman berumur 1-6 mst dengan menyemprotkan Provibio ${ }^{\circledR}$ pada konsentrasi $2 \mathrm{ml} \mathrm{L}^{-1}$.

Perompesan tunas air yang tumbuh di ketiak daun dan di bawah bunga pertama dirompes dengan tangan yang bersih. Bunga pertama sampai bunga ketiga dibuang. Pemanenan dilakukan saat bobot cabe sudah maksimal dengan kriteria bentuk padat dan warna merah menyala. Pemanenan dilakukan 3 hari sekali.

Parameter yang diamati adalah tinggi tanaman, jumlah cabang, panjang buah, bobot/ buah,dan bobot buah/tanaman. Pengamatan tinggi tanaman dan jumlah cabang dilakukan setiap minggu diawali saat tanaman cabe berumur 2 mst sampai muncul bunga pertama 
Pengamatan panjang buah, bobot/buah dan bobot buah/tanaman dilakukan saat pemanenan.

\section{HASIL DAN PEMBAHASAN}

Hasil analisis ragam menunjukkan interaksi kombinasi media tanam dan penambahan POC memberikan pengaruh nyata terhadap tinggi tanaman yang dapat dilihat pada Gambar 1. Dari awal pengamatan sampai pengamatan terakhir, menunjukkan kombinasi media tanam tanah + pupuk kandang + sekam bakar $=1: 1: 1$ dengan $70 \%$ NPK +150 ml tanaman ${ }^{-1}$ POC adalah tanaman tertinggi dan tinggi tanaman terendah terdapat pada kombinasi media tanam tanah + pupuk kandang $=1: 1$ dengan $70 \% \mathrm{NPK}+50 \mathrm{ml}$ tanaman ${ }^{-1}$ POC.

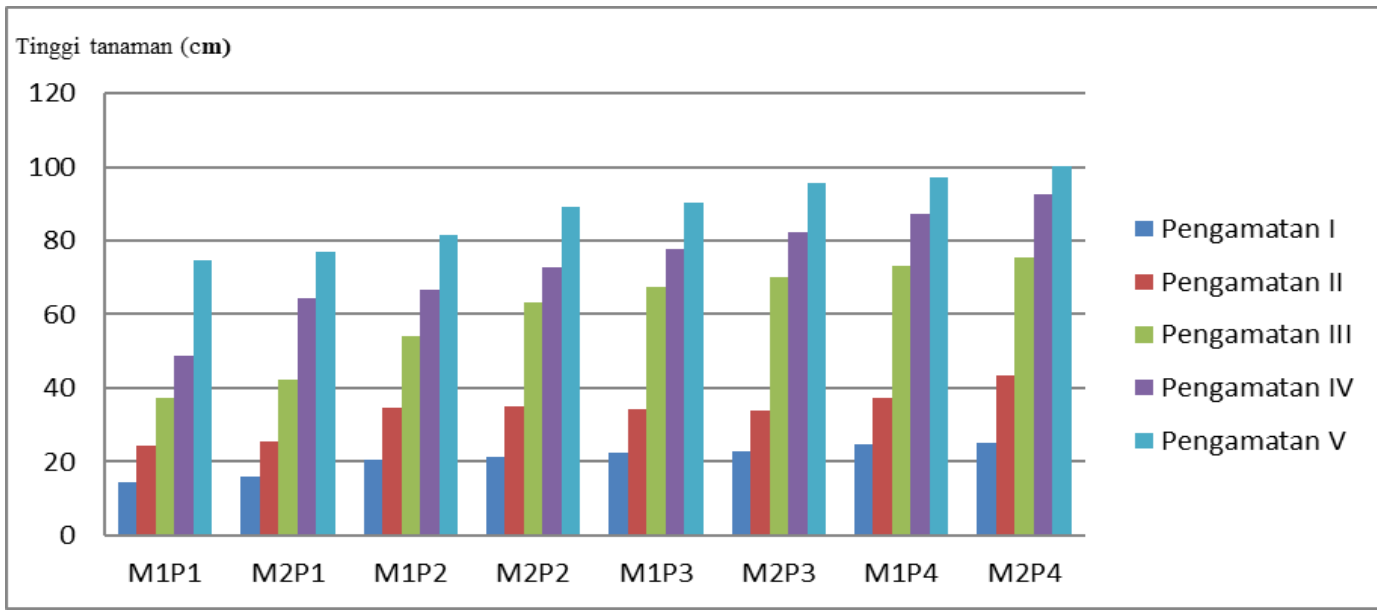

Gambar 1. Interaksi Media Tanam dan Penambahan POC terhadap Tinggi Tanaman Cabe Umur 2 - 6 mst

Tabel 1 menunjukkan bahwa interaksi kombinasi media tanam tanah + pupuk kandang + sekam bakar $=1: 1: 1$ pada tinggi tanaman dan jumlah cabang tanaman cabe berbeda nyata terhadap perlakuan media tanam tanah + pupuk kandang $=1: 1$. Perlakuan interaksi kombinasi media tanam tanah + pupuk kandang + sekam bakar $=1: 1: 1$ memperlihatkan tinggi tanaman tertinggi $(95.79 \mathrm{~cm})$ dan jumlah cabang terbanyak (3.72 buah). Perlakuan penambahan POC (70\% NPK + 150 ml.tanaman-1 POC) menghasilkan tinggi tanaman tertinggi $(94.78 \mathrm{~cm})$ dan jumlah cabang terbanyak (4.19 buah) pada tanaman cabe berbeda nyata dengan semua perlakuan penambahan POC. Tinggi tanaman terendah $(82.39 \mathrm{~cm})$ dan jumlah cabang tersedikit (2.94 buah) terdapat pada perlakuan $70 \%$ NPK +50 $\mathrm{ml}$ tanaman ${ }^{-1}$ POC.

Berdasarkan analisis ragam pengaruh kombinasi media tanam dan penambahan POC berpengaruh nyata terhadap tinggi tanaman dan jumlah cabang pada umur 6 mst. Tabel 2 memperlihatkan pengaruh kombinasi media tanam dan penambahan POC pada tinggi tanaman dan jumlah cabang tanaman cabe berbeda nyata terhadap semua perlakuan. Perlakuan kombinasi media tanam tanah + pupuk kandang + sekam bakar $=1: 1: 1$ dengan $70 \%$ NPK + 150 ml.tanaman-1 POC memiliki tinggi tanaman tertinggi $(100.25 \mathrm{~cm})$ dan jumlah cabang terbanyak (5.50 buah) pada tanaman cabe berbeda nyata terhadap semua perlakuan. Tinggi tanaman terendah $(74.54 \mathrm{~cm})$ terdapat pada kombinasi perlakuan media tanam tanah + pupuk kandang $=1: 1$ dengan perlakuan $70 \% \mathrm{NPK}+50 \mathrm{ml} \mathrm{tanaman}^{-1}$ POC dan jumlah cabang tersedikit (2.38 buah) pada perlakuan kombinasi media tanam tanah + pupuk kandang + sekam bakar $=1: 1: 1$ dengan $70 \% \mathrm{NPK}+100$ $\mathrm{ml}$ tanaman ${ }^{-1}$ POC. 
Tabel 1. Pengaruh Tunggal Media Tanam dan Penambahan POC terhadap Tinggi Tanaman dan Jumlah Cabang Tanaman Cabe pada Umur 6 mst

\begin{tabular}{lcc}
\hline \multicolumn{1}{c}{ Perlakuan } & Tinggi tanaman (cm) & Jumlah cabang (buah) \\
\hline Media & & \\
Tanah + pupuk kandang = 1:1 & $80.51 \mathrm{~b}$ & $3.03 \mathrm{~b}$ \\
Tanah+ pupuk kandang + sekam & $95.79 \mathrm{a}$ & $3.72 \mathrm{a}$ \\
bakar = 1:1:1 & & \\
\hline POC & & \\
\hline 100\% NPK= kontrol & $86.39 \mathrm{c}$ & $3.00 \mathrm{c}$ \\
$70 \%$. NPK + 50 ml.tanaman-1 POC & $86.15 \mathrm{c}$ & $2.94 \mathrm{c}$ \\
$70 \%$. NPK + 100 ml.tanaman-1 POC & $89.29 \mathrm{~b}$ & $3.38 \mathrm{~b}$ \\
$70 \%$ NPK + 150 ml.tanaman-1 POC & $94.78 \mathrm{a}$ & $4.19 \mathrm{a}$ \\
\hline KK $(\%)$ & 19,24 & 16,89 \\
\hline
\end{tabular}

Keterangan : Angka-angka yang diikuti oleh huruf yang sama pada kolom yang sama tidak berbeda nyata berdasarkan uji DMRT pada taraf 5\%

Tabel 2. Pengaruh Kombinasi Media Tanam dan Penambahan POC terhadap Tinggi dan Jumlah Cabang Tanaman Cabe pada Umur 6 mst

\begin{tabular}{ccc}
\hline Perlakuan & Tinggi tanaman $(\mathrm{cm})$ & Jumlah cabang (buah) \\
\hline M2P4 & $100.25 \mathrm{a}$ & $5.50 \mathrm{a}$ \\
M1P4 & $97.19 \mathrm{~b}$ & $4.00 \mathrm{~b}$ \\
M2P3 & $95.50 \mathrm{c}$ & $2.38 \mathrm{c}$ \\
M1P3 & $90.25 \mathrm{~d}$ & $3.00 \mathrm{~d}$ \\
M2P2 & $89.31 \mathrm{~d}$ & $2.88 \mathrm{~d}$ \\
M1P2 & $81.40 \mathrm{e}$ & $2.75 \mathrm{~d}$ \\
M2P1 & $76.80 \mathrm{f}$ & $3.50 \mathrm{e}$ \\
M1P1 & $74.54 \mathrm{~g}$ & $3.00 \mathrm{~d}$ \\
\hline Kk (\%) & 19,24 & 16,89
\end{tabular}

Keterangan : Angka-angka yang diikuti oleh huruf yang sama pada kolom yang sama tidak berbeda nyata berdasarkan uji DMRT pada taraf $5 \%$.

Hasil analisis ragam interaksi kombinasi media tanam dengan penambahan POC pada tanaman cabe memberikan pengaruh nyata terhadap panjang buah, bobot buah buah ${ }^{-1}$ dan bobot buah per tanaman. Pada Tabel 3 memperlihatkan panjang buah terpanjang $(11.78 \mathrm{~cm})$, bobot buah buah $^{-1}$ terberat $(3.47 \mathrm{~g})$ dan bobot buah per tanaman terberat $(79.09 \mathrm{~g})$ padainteraksikombinasi media tanam tanah + pupuk kandang + sekam bakar $=$ 1: 1: 1 yang berbeda nyata dengan perlakuan kombinasi media tanam tanah + pupuk kandang $=1: 1$. Perlakuan penambahan POC $(70 \%$ NPK $+150 \mathrm{ml}$ tanaman ${ }^{-1}$ POC) menunjukkan panjang buah terpanjang $(12.64 \mathrm{~cm})$, bobot buah buah ${ }^{-1}$ terberat (3.86 g), dan bobot buah per tanaman terberat $(84.31 \mathrm{~g})$ berbeda nyata dengan perlakuan penambahan POC lainnya. Panjang buah terpendek $(10.71 \mathrm{~cm})$, bobot buah buah ${ }^{-1}$ teringan $(2.94 \mathrm{~g})$ pada kombinasi media tanam tanah + pupuk kandang + sekam bakar $=$ 1: 1: 1 dengan $70 \%$ NPK $+50 \mathrm{ml}$ tanaman ${ }^{-1}$ POC dan bobot buah per tanaman terendah $(70.13 \mathrm{~g})$ pada perlakuan kombinasi media tanam tanah + pupuk kandang + sekam bakar $=1: 1$ : 1 dengan $70 \% \mathrm{NPK}+100 \mathrm{ml} \mathrm{tanaman}^{-1}$ POC.

Berdasarkan hasil analisis ragam kombinasi media tanam dan penambahan POC berpengaruh nyata terhadap panjang buah, bobot buah buah $^{-1}$ dan bobot buah per tanaman. Tabel 4 memperlihatkan perlakuan kombinasi media tanam tanah + pupuk 
kandang + sekam bakar $=1: 1: 1$ dengan $70 \%$ NPK $+150 \mathrm{ml} \mathrm{tanaman}^{-1}$ POC menunjukkan panjang buah terpanjang $(13.67 \mathrm{~cm})$, bobot buah buah ${ }^{-1}$ terberat $(4.5 \mathrm{~g})$, dan bobot buah per tanaman terberat (92.06 g) yang berbeda nyata dengan semua perlakuan. Panjang buah terpendek $(7.75 \mathrm{~cm})$, bobot buah buah ${ }^{-1}$ teringan $(2.38 \mathrm{~g})$ pada kombinasi media tanam tanah + pupuk kandang + sekam bakar $=1: 1: 1$ dengan $70 \% \mathrm{NPK}+50$ $\mathrm{ml}$ tanaman ${ }^{-1}$ POC dan bobot buah per tanaman terendah (56.47 g) pada perlakuan kombinasi media tanam tanah + pupuk kandang + sekam bakar $=1: 1$ : 1 dengan $70 \%$ NPK +50 ml tanaman $^{-1}$ POC.

Tabel 3. Interaksi Media Tanam dan Penambahan POC terhadap Panjang Buah, Bobot per buah, dan Bobot buah per tanaman Tanaman Cabe

\begin{tabular}{llll}
\hline \multicolumn{1}{c}{ Perlakuan } & $\begin{array}{c}\text { Panjang buah } \\
(\mathrm{cm})\end{array}$ & $\begin{array}{c}\text { Bobot per } \\
\text { buah }(\mathrm{g})\end{array}$ & $\begin{array}{c}\text { Bobot buah per } \\
\text { tanaman }(\mathrm{g})\end{array}$ \\
\hline Media tanam & \multicolumn{3}{l}{} \\
\hline Tanah + pupuk kandang = 1:1 & $10.9 \mathrm{~b}$ & $3.03 \mathrm{~b}$ & $76.76 \mathrm{~b}$ \\
\hline $\begin{array}{l}\text { Tanah + pupuk kandang + sekam bakar } \\
=1: 1: 1\end{array}$ & $11.78 \mathrm{a}$ & $3.47 \mathrm{a}$ & $79.09 \mathrm{a}$ \\
\hline POC & & & \\
\hline $100 \%$ NPK= kontrol & $10.82 \mathrm{~b}$ & $2.97 \mathrm{~b}$ & $75.96 \mathrm{c}$ \\
\hline $70 \%$ NPK + 50 ml.tanaman-1 POC & $10.71 \mathrm{~b}$ & $2.94 \mathrm{bc}$ & $76.29 \mathrm{c}$ \\
\hline $70 \%$. NPK + 100 ml.tanaman-1 POC & $10.91 \mathrm{~b}$ & $3.13 \mathrm{~b}$ & $70.13 \mathrm{~b}$ \\
\hline $70 \%$ NPK + 150 ml.tanaman-1 POC & $12.64 \mathrm{a}$ & $3.86 \mathrm{a}$ & $84.31 \mathrm{a}$ \\
\hline KK (5) & 19.55 & 17.99 & 12.19 \\
\hline
\end{tabular}

Keterangan : Angka-angka yang diikuti oleh huruf yang sama pada kolom yang sama tidak berbeda nyata berdasarkan uji DMRT pada taraf 5\%

Memperhatikan hasil penelitian, secara umum interaksi kombinasi media tanam tanah + pupuk kandang + sekam bakar = 1: 1: 1 memberikan pengaruh lebih baik dibandingkan kombinasi media tanam tanah + pupuk kandang $=$ 1:1 pada parameter tinggi tanaman, jumlah cabang, panjang buah, bobot buah buah $^{-1}$, dan bobot buah per tanaman tanaman cabe. Perlakuan penambahan POC $(70 \%$ NPK $+150 \mathrm{ml}$ tanaman $^{-1}$ POC) juga memberikan pengaruh yang baik terhadap parameter tinggi tanaman, jumlah cabang, panjang buah, bobot buah buah ${ }^{-1}$, dan bobot buah per tanaman tanaman cabe. Demikian juga kombinasi media tanam tanah + pupuk kandang + sekam bakar $=1: 1: 1$ dengan penambahan POC (70\% NPK + $150 \mathrm{ml}$ tanaman ${ }^{-1}$ POC) memperlihatkan pengaruh yang baik juga terhadap parameter tinggi tanaman, jumlah cabang, panjang buah, bobot buah buah $^{-1}$, dan bobot buah per tanaman tanaman cabe.
Media tanam secara umum berperan menjaga kelembaban daerah sekitar akar, menyediakan cukup udara, dan dapat menahan ketersediaan unsur hara. Sekam bakar merupakan media tanam yang berperan menjaga kelembaban. Hal ini menurut Wuryan (2008), sekam bakar memiliki pori-pori makro dan mikro yang hampir seimbang, sehingga lebih porous dan sirkulasi udara yang dihasilkan cukup baik serta memiliki daya serap air yang tinggi. Hayati (2010) menambahkan sekam padi dapat mempertahankan kelembaban tanah yang tinggi dan meningkatkan kadar hara dalam tanah yang dapat dimanfaatkan tanaman.

Semakin banyak pupuk cair yang diberikan pada tanaman, akan semakin baik pertumbuhan tanaman cabe. Hal ini disebabkan pemberian pupuk organik cair dapat menyebabkan lingkungan tumbuh dan media tanam lebih baik sehingga dapat merangsang pertumbuhan vegetatif 
dan generatif tanaman (Driyunitha dan Pairi, 2015).

Perlakuan $70 \%$ NPK $+150 \mathrm{ml}$ tanaman ${ }^{-1} \mathrm{POC}$ dengan kombinasi media tanam tanah + pupuk kandang + sekam bakar $=1: 1: 1$ dapat memperbaiki sifat fisik, kimia dan biologi tanah. Tekstur tanah yang lebih remah menyebabkan pertumbuhan dan perkembangan akar lebih baik sehingga fungsi akar dalam menyerap air dan unsur hara akan lebih meningkat. Selain itu kandungan unsur hara dari N, P dan K serta POC dapat menambah ketersediaan unsur hara tanah, sehingga unsur hara makro yang esensial bagi pertumbuhan vegetatif mencukupi untuk pembelahan dan pembesaran sel serta menyediakan energi bagi metabolisme tanaman. Hal ini sesuai dengan yang dikemukan oleh Hulopi (2006) cit. Hapsoh et al. (2017), pertumbuhan terutama tinggi tanaman dapat ditingkatkan oleh pupuk NPK, diduga karena pupuk N, P, dan K yang dapat berperan merangsang pertumbuhan vegetatif tanaman.

Tabel 4. Pengaruh Kombinasi Media Tanam dan Penambahan POC terhadap Panjang Buah, Bobot per buah, dan Bobot buah per tanaman tanaman cabe

\begin{tabular}{cccc}
\hline Perlakuan & $\begin{array}{c}\text { Panjang buah } \\
(\mathrm{cm})\end{array}$ & $\begin{array}{c}\text { Bobot per buah } \\
(\mathrm{g})\end{array}$ & $\begin{array}{c}\text { Bobot buah per tanaman } \\
(\mathrm{g})\end{array}$ \\
\hline M2P4 & $13.67 \mathrm{a}$ & $4.5 \mathrm{a}$ & $92.06 \mathrm{a}$ \\
M2P3 & $12.10 \mathrm{~b}$ & $3.28 \mathrm{~b}$ & $76.56 \mathrm{~b}$ \\
M2P2 & $11.60 \mathrm{~b}$ & $3.23 \mathrm{~b}$ & $73.53 \mathrm{c}$ \\
M1P2 & $10.98 \mathrm{~b}$ & $3.13 \mathrm{~b}$ & $69.44 \mathrm{~d}$ \\
M1P4 & $10.85 \mathrm{bc}$ & $3.13 \mathrm{~b}$ & $81.33 \mathrm{e}$ \\
M1P3 & $10.50 \mathrm{bc}$ & $2.97 \mathrm{~b}$ & $71,26 \mathrm{c}$ \\
M2P1 & $9.33 \mathrm{c}$ & $2.60 \mathrm{c}$ & $66.74 \mathrm{f}$ \\
M1P1 & $8.75 \mathrm{c}$ & $2.58 \mathrm{c}$ & $66.47 \mathrm{f}$ \\
\hline KK $(\%)$ & 19.55 & 17.99 & 12.19 \\
\hline
\end{tabular}

Keterangan : Angka-angka yang diikuti oleh huruf yang sama pada kolom yang sama tidak berbeda nyata berdasarkan uji DMRT pada taraf 5\%

Pemakaian media tanam yang sesuai serta penambahan nutrisi dengan pupuk cair memberikan produksi yang lebih baik terhadap tanaman. Menurut Endah et al (2017), kandungan unsur hara Nitrogen, Fosfor dan Kalium yang tinggi pada sekam bakar akan dapat memperbaiki struktur tanah.

Dari hasil penelitian terlihat bahwa pemakaian media tanam tanah, pupuk kandang dan sekam bakar $=1: 1: 1$ yang dikombinasikan dengan penambahan $70 \%$. NPK +150 mltanaman $^{-1} \mathrm{POC}$ memberikan hasil yang lebih baik terhadap produksi cabe (panjang buah, bobot buah buah ${ }^{-1}$, dan bobot buah per tanaman).

Media tumbuh merupakan salah satu faktor eksternal yang sangat mempengaruhi pertumbuhan dan hasil tanaman. Disamping itu pertumbuhan generatif tanaman selain ditentukan oleh faktor genetik dan lingkungan selama fase generatif juga sangat ditentukan oleh pertumbuhan vegetatifnya.

\section{SIMPULAN}

Hasil penelitian ini dapat disimpulkan bahwa media tanam dan penambahan POC mempengaruhi pertumbuhan vegetatif dan produksi tanaman cabe yang diperlakukan. Semakin banyak POC yang ditambahkan semakin baik pertumbuhan dan produksinya. Kombinasi media tanam tanah + pupuk kandang + sekam bakar $=1: 1: 1$ dengan $70 \% \mathrm{NPK}+150$ ml.tanaman ${ }^{-1}$ POC menunjukkan data paling tinggi pada semua parameter pengamatan. 


\section{DAFTAR PUSTAKA}

Anonim. 2009. Sekam Bakar bagi Adenium.

http://wartawarga.gunadarma.ac.id /2009/12/sekam-bakar-bagiadenium/. [13 Mei 2019]

BPP Ketindan. 2017. Peran Arang Sekam dalam Perbaiki Struktur Tanah di Budidaya Cabai merah. https://bbppketindan.bppsdmp.pertan ian.go.id/blog/peran-arang-sekamdalam-perbaikan-struktur-tanah-dibudidaya-cabai-merah [ 11 Oktober 2018]

BPS. 2018. Statistik Tanaman Sayuran dan Buah-buahan Semusim Indonesia 2017.

https://www.bps.go.id/publication/20 18/10/05/bbd90b867a6ee372e7f51c4 3/statistik-tanaman-sayuran-danbuah---buahan-semusim-indonesia2017.html. [1Desember 2018]

Cristiyani, 2013. Penggunaan Beberapa Jenis Media Tanam pada Pembibitan Akasia. Skripsi. Fakultas Pertanian Universtas Muhammadiyah Jakarta

Direktorat Jenderal Hortikultura. 2015. Statistik Produksi Hortikultura Tahun 2014.

http://hortikultura.pertanian.go.id/wp content/uploads/2016/02/Statistik-

Produksi-2014.pdf [ 3 Januari 2017]

Driyunitha dan R Pairi. 2015 .Pengaruh Konsentrasi Pupuk Organik Cair yang Didekomposisi dengan Trichoderma sp terhadap Pertumbuhan dan Produksi Tanaman Cabe Besar (Capsicum sp) Var. Lokal Toraja. Jurnal Kip 4(2):853878

Durahim dan Hendromono. 2001. Kemungkinan Penggunaan Limbah Organik Sabut Kelapa Sawit dan Sekam Padi sebagai Campuran Top Soil untuk Media Pertumbuhan Bibit Mahoni (Swietenia macrophylla King). Buletin Penelitian Hutanno

Endah, Naomi Pratiwi, Bistok Hasiholan Simanjuntak, dan Dina Banjarnahor.
2017. Pengaruh Campuran Media Tanam terhadap Pertumbuhan Tanaman Stroberi (Fragaria vesca L.) sebagai Tanaman Hias Taman Vertikal. Agric Jurnal Ilmu Pertanian Vol. 29, No. 1, Juli 2017: 11 - 20

Hadisuwito, Sukamto, 2010. Membuat Pupuk Kompos Cair. Jakarta: Agro Media

Hapsoh, Gusmawartati, Al Ichsan Amri dan Asty Diansyah. 2017. Respons Pertumbuhan dan Produksi Tanaman Cabai Keriting (Capsicum annuum L.) terhadap Aplikasi Pupuk Kompos dan Pupuk Anorganik di Polibag. J. Hort. Indonesia 8(3), April 2017: 203-208..

Hayati, E. 2010. Respon Jagung Manis (Zea mays, Sacharata Shout) terhadap Penggunaan Mulsa dan Pupuk Organik. Jurnal Agrista Vol.14, No.1.

Kementerian Pertanian RI. 2018. Statistik Pertanian 2017. Jakarta. Pusat Data dan Sistem Informasi Pertanian Kementerian Pertanian Republik Indonesia. http://pangan.litbang.pertanian.go.id/ files/Statistik/StatistikPertanian2017. pdf [ 1 Desember 2018]

Marlina N, dan Rusnandi D. 2007. Teknik Aklimatisasi Bibit Anthurium pada Beberapa Media Tanam. Bul. Tek. Pertanian. 12(1): 38-40.

Musnamar, E.I. 2005. Pupuk Organik. Jakarta: Penebar Swadaya

Nurahmi, Erida, T. Mahmud, Sylvia Rossiana S. 2011. Efektivitas Pupuk Organik terhadap Pertumbuhan dan Hasil Cabai Merah.Jurnal Floratek 5: 158-164

Rukmana dan Herdi Tudirachman. 2017. Untung Selangit dari Agribisnis Cabai. Yogyakarta. Lily Publisher.

Setyorini, D. 2005. Pupuk Organik Tingkatkan Produksi Pertanian. http://www. Pustakadeptan.go.id/publikasi/wr276057.pdf [12 Desember 2017]. 